\title{
Hatóanyag-kibocsátó koszorúérsztentek bevonatának vizsgálata
}

\section{Examination of Coating of Drug-Eluting Coronary Stents}

\author{
Asztalos Lilla, ${ }^{1}$ Horicsányi Krisztina ${ }^{2}$ \\ ${ }^{1}$ Budapesti Müszaki és Gazdaságtudományi Egyetem, Gépészmérnöki Kar, Anyagtudomány és Technoló- \\ gia Tanszék, Budapest, Magyarország, lilla@eik.bme.hu \\ ${ }^{2}$ Budapesti Müszaki és Gazdaságtudományi Egyetem, Gépészmérnöki Kar, Mechatronika, Optika és Gépé- \\ szeti Informatika Tanszék, Budapest, Magyarország, horicsanyi.krisztina@gmail.com
}

\begin{abstract}
Drug-eluting stents provide a solution for treating restenosis in arteries expanded by using conventional bare metal stents, but there are a small number of publications on the processes of coating damage established due to the various effects that occur during the life cycle of the stent. In the current research damage to the coating was investigated along with the effects of damage on the corrosion resistance of the stent in multiple ways. This research investigates not only traditional drug eluting stents with polymer matrix, but also the new generation of polymer-free types.
\end{abstract}

Keywords: coronary stent, drug-eluting stent, coating, corrosion.

\section{Összefoglalás}

A hatóanyag-kibocsátó sztentek megoldást jelentettek a hagyományos fémsztentekkel kezelt artériákban kialakult resztenózis kezelésére, de a sztent teljes életciklusa alatt fellépő, különböző hatásokra bekövetkező károsodási folyamatairól kevés publikáció lelhető fel. A jelenleg folyó kutatásban több szempontból is vizsgáljuk a bevonat károsodásait és annak hatását a sztentnek a korrózióval szembeni ellenállására. A vizsgálatok során nemcsak a hagyományos, polimer mátrixba kevert hatóanyagot kibocsátó sztenteket vizsgáltunk, hanem új generációs, polimermentes típusokat is.

Kulcsszavak: koszorúérsztent, hatóanyag-kibocsátó sztent, bevonat, korrózió.

\section{A hatóanyag-kibocsátó sztentek}

A 2000-es évek elején jelentek meg ezek az ún. hatóanyag-kibocsátó sztentek, amelyek segítségével a neointimális proliferációt, az insztent resztinózis elsődleges okát 5-10\%-ra sikerült visszaszorítani. Bár a fémsztentek (BMS) architektúrájának és mechanikai tulajdonságainak optimalizálása ezzel párhuzamosan szintén a resztenózis kialakulásának csökkentéséhez vezetett, a gyógyszerkibocsátó sztentek alkalmazása nem szorult háttérbe [1].

A hatóanyagnak a sztentre történő felviteléhez a technikákat három csoportba sorolhatjuk: (a) a hatóanyagot közvetlenül a fém felületére viszik fel, (b) a hatóanyagnak a fémsztent felületi pórusaiba történő bejuttatása, (c) a hatóanyagot egy polimerhez kötik, amit majd aztán bevonatként használnak az implantátum felületén [1, 2]. A sztentek felületére nemcsak olyan bevonat kerülhet, amely gyógyszeres hatóanyagot bocsát ki, hanem gyógyszer nélküli bevonatos sztentek is léteznek. Előbbi sztenteket aktív, az utóbbiakat passzív bevonatosnak nevezzük [3]. A passzív bevonatú sztentek fő előnye, hogy „láthatatlanná” teszik a fémeszközt a környező szövetek számára. A passzív bevonatoknak biztosítaniuk kell az optimális kölcsönhatást a vérrel és az artéria 
falával [4]. A bevonatkészítési technikák közül a (c) módszer a legelterjedtebb napjainkban, viszont a nem lebomló polimerek és a lassú gyógyszerkioldódás miatti hosszú távú problémák kiküszöbölése érdekében az (a) módszerrel készített, polimer hordozóanyag nélküli gyógyszeres sztentek is egyre több gyártó termékpalettáján jelennek meg [5].

A sztentbevonatokkal szemben támasztott legfontosabb követelmények a megfelelő tapadás és hatóanyag-kibocsátási képesség, de fontos maga a hordozó polimer alapanyaga, a bevonat felületének a minősége stb. A BME Anyagtudomány és Technológia Tanszékén több korábbi kutatás is foglalkozott a kereskedelmi forgalomban kapható bevonatos sztentek vizsgálatával és poliuretán alapanyagú bevonatok fejlesztésével is [6, 7]. A bevonatspecifikus kutatások óta eltelt időben több, korábban nem vizsgált bevonattípus jelent meg a piacon, valamint a lebomló műanyagok és polimer hordozóanyag nélküli típusok is egyre nagyobb teret hódítanak [8, 9]. Az újfajta bevonattípusokból eddigi kutatásaink során everolimus hatóanyagot tartalmazó, poli(vinilidén-fluorid-ko-hexafluor-propilén) (a továbbiakban PVDF-HFP) bevonatú, platina-króm ötvözésű acélsztentek bevonatkárosodásait vizsgáltuk [10], jelen kutatásunkban viszont már többféle alapanyagot és bevonattípust is megfigyeltünk. Korróziós méréseket szintén végeztünk koszorúérsztenteken [11], a mérések újragondolásában és kiértékelésében a Pécsi Tudományegyetem Általános és Fizikai Kémiai Tanszéke volt segítségünkre.

\section{A kutatómunka}

\subsection{A bevonatkárosodás vizsgálata}

A hatóanyag-kibocsátó sztentek bevonatát elektronmikroszkóppal vizsgáljuk. Ez idáig azonban az elektronmikroszkópos (SEM) vizsgálathoz a sztenteket egy kétoldalú speciális ragasztószalaggal rögzítettük a mintatartóhoz. A módszer során problémát jelentett, hogy a sztent új pozícióba állításához ki kellett vennünk a mikroszkóp kamrájából, le kellett vennünk a ragasztószalagról, majd az elmozdítás után újra kellett rögzíteni azt. Ez a folyamat a vákuumozás miatt időigényes, és a sztent minden egyes levételekor a ragasztószalag károsíthatja annak bevonatát.

A probléma kiküszöböléséhez fejlesztettünk egy olyan befogó- és mozgatókészüléket, amellyel a kamra kinyitása nélkül lehet forgatni a vizsgált sztentet, azért, hogy a palástja mentén vizsgálni tudjuk a sztent bevonatát. A tervezett eszközből elkészítettünk egy prototípust (1. ábra). A sztentforgatót a BME ATT-n található Zeiss EVO MA 10 típusú elektronmikroszkóp kamrájába terveztük. A prototípuseszköz elfér az elektronmikroszkóp kamrájában (2. ábra), a tengely mozgatásáért felelős léptetőmotort Arduino szabad szoftveres, nyílt forráskódú elektronikai fejlesztőplatformra szerelve, Raspberry Pi egykártyás számítógéppel programozva, WiFi-n keresztül tudjuk irányítani, a hálózaton keresztüli irányítás pedig zárt kamraállásban is müködőképes. A prototípuseszköz fejlesztési céljai között szerepel a további méretcsökkentés és az elektronikai részekre burkolat tervezése.

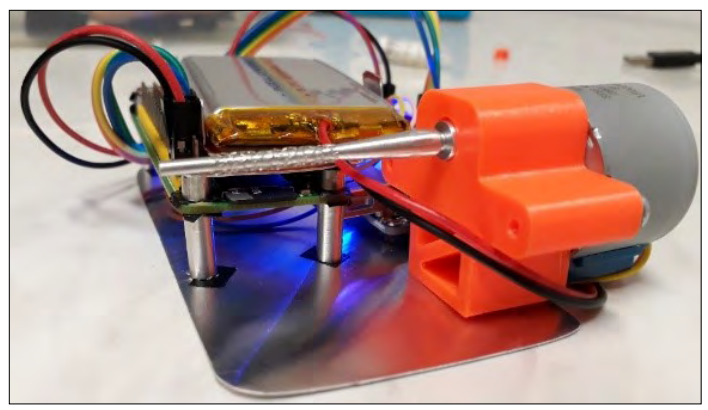

1. ábra. A sztentbefogó és -forgató eszköz prototípusa

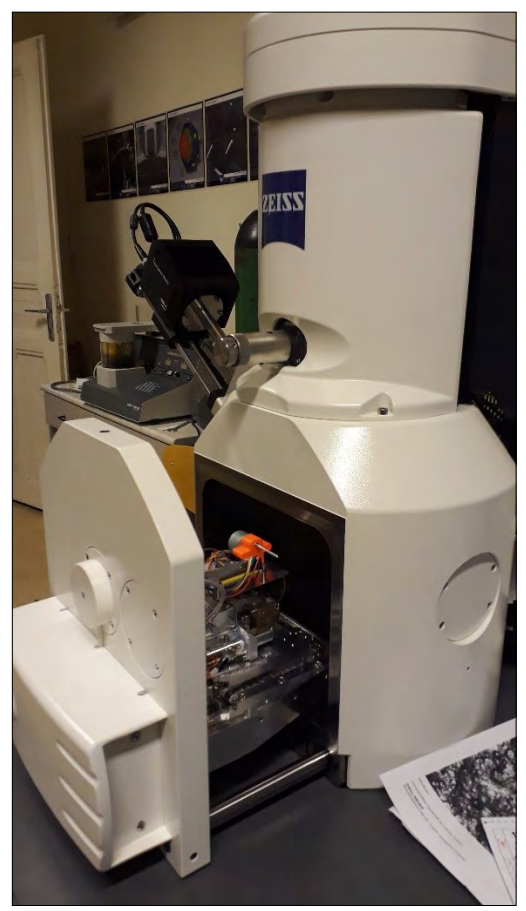

2. ábra. A sztentbefogó-prototípus elhelyezése a Zeiss EVO MA 10 elektronmikroszkóp kamrájában 
A kutatásunk során a korábban is vizsgált PVDFHFP bevonatú, platina-króm ötvözésű acél sztentek mellett vizsgáltunk amorf szilícium-karbid bevonatos, kobalt-króm ötvözésű acélsztenteket, valamint polimer kötőréteg nélküli, hatóanyag-kibocsátó bevonatos sztentet is.

$\mathrm{Az}$ amorf szilícium-karbid bevonat a PVDF-HFP bevonathoz hasonlóan, csupán a tágítás hatására több helyen, jellemzően a bordaívekben szakadozott fel (3. ábra). A két bevonattípust összehasonlítva a PVDF-HFP bevonat károsodott kisebb mértékben.

A polimer hordozóanyag nélküli, hatóanyag-kibocsátó bevonatos sztentek esetében a károsodás sokkal nagyobb mértékű, ami részben azzal magyarázható, hogy a folyadékközegben történő tágítás során a bevonat egy része már a tágítás előtt leoldódott a sztent felületéről, valamint a bevonat vastagsága is sokkal kisebb ezeken a típusokon (4. és 5. ábra).

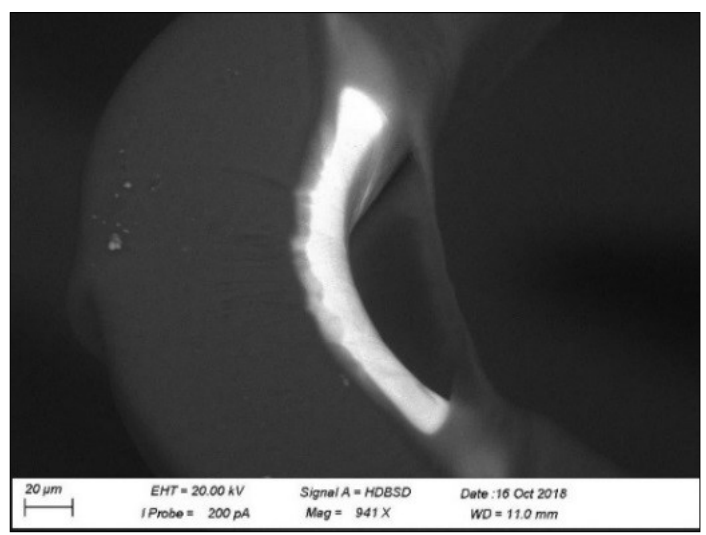

3. ábra. Amorf szilícium-karbid bevonat károsodása tágítás után, kobalt-króm ötvözet alapanyagú sztenten

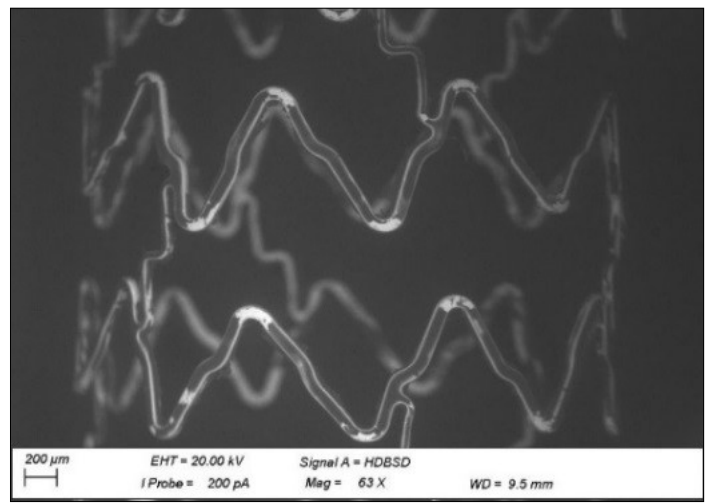

4. ábra. Polimer hordozóanyag nélküli, hatóanyag-kibocsátó bevonatos sztent két gyürüje elektronmikroszkópos képen

\section{2. Értékelési rendszer a bevonatkárosodá- sok osztályozására}

Az előzőekben láthattuk, hogy a sztentbevonatok károsodása leginkább a fémfelülettől való elválásban mutatkozik meg. Ez alapján egy objektív kiértékelési rendszerhez azt kell megvizsgálnunk, hogy a bevonat összfelületének mekkora része vált le a fémről. Azért, hogy a különböző méretű sztentek egymással összehasonlíthatók legyenek, a károsodott felület teljes felülethez vett aránya alapján célszerű mérőszámot képezni.

A pásztázó elektronmikroszkóppal nem tudunk olyan kis nagyítású képet készíteni, hogy a sztent teljes hossza egy képen látható legyen, ezért a sztentet szakaszonként fényképezzük be, majd képszerkesztő program segítségével összeállítjuk a sztent terítékét.

Visszaszórtelektron-detektálással a bevonat hibái jól elkülöníthetők, ugyanis az ép polimer-bevonat sötétebb, míg a károsodott szakaszokon előtűnő fém világosabb színnel jelenik meg a képeken (3-5. ábra). Ezt kihasználva egy megfelelő szoftver segítségével meg lehet határozni azt, hogy a sztent felületének mekkora hányadán károsodott a bevonat. A képelemzéshez először egy MATLAB-kóddal levágjuk a sztentet a kép többi részéről, hogy a sötét háttér ne okozzon gondot a képelemzés során. Ezt követően binarizáljuk a képeket, majd a különböző sötétségű pixelek számolásával megkapunk egy mérőszámot, amely a károsodott felületnek a vizsgált vetületen vett aránya. A képfeldolgozás lépései a 6 . ábrán láthatóak. A szemléltető ábrák a sztentforgató berendezés rendelkezésre állása előtt készültek. A sztentforgató berendezés fejlesztésével elérhetjük, hogy a bevonatkárosodás mértékét a sztent teljes külső felületére nézve meg tudjuk határozni.

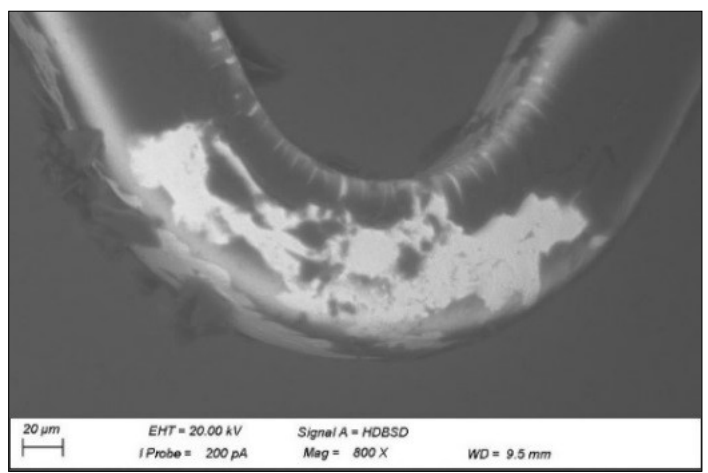

5. ábra. A polimer hordozóanyag nélküli, hatóanyag-kibocsátó bevonatos sztent bordáinak csúcsán a bevonat nagymértékü repedezése és lemezkék formájában való leválása figyelhető meg 


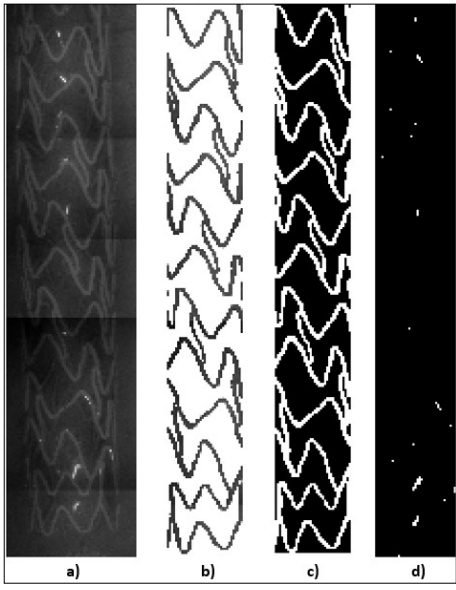

6. ábra. A képfeldolgozási folyamat lépései:

a) Az elektronmikroszkópos képek összeállítása.

b) A sztent körülvágása. c) A kép binarizálása és komplementálása. d) A bevonatsérülések helye a sztent felületén.

\subsection{Korróziós vizsgálat: a nyitott áramköri potenciál mérése}

A nyitott áramköri potenciállal (OCP) jellemezhető az anyag termodinamikai hajlama az elektrokémiai oxidációra. Az OCP-mérés során a munkaelektródra nem vezetünk áramot, így egy ún. egyensúlyi vagy nyitott áramköri potenciál fejlődése rögzíthető a fém és az elektrolitoldat között. A nyitott áramköri potenciál változása az idő függvényében utalhat:

- oxidációra, ekkor a nyitott áramköri potenciál csökkenő tendenciát mutat;

- passzív réteg képződésére, ekkor a szabadpotenciál növekvő tendenciát mutat; valamint

- inhibitort tartalmazó közegben a potenciál konstans [12].

A mérési módszer előnye, hogy független a próbatestek méretétől, ezért a különböző átmérőjü és hosszúságú sztentek könnyebben összehasonlíthatók, mint egyéb elektrokémiai méréseknél, továbbá a sztentfelületek nagyságának pontos meghatározása is összetett folyamat, emiatt érdemes az olyan módszereket előtérbe helyezni, amelyeknél ez a tényező kizárható. Az OCP-méréseket standard, kételektródos cellában kell elvégezni. A mérés során elektrolitnak foszfát pufferoldatot (PBS) használtunk, amelynek összetétele: $800 \mathrm{~g}$ vízhez $8 \mathrm{~g} \mathrm{NaCl} ; 0,2 \mathrm{~g} \mathrm{KCl} ; 1,44 \mathrm{~g} \mathrm{Na}_{2} \mathrm{HPO}_{4}$; 0,24 $\mathrm{g} \mathrm{KH}_{2} \mathrm{PO}_{4}$, a pH értéke 7,4-re beállítva. Referenciaelektródnak $\mathrm{Hg} / \mathrm{Hg}_{2} \mathrm{Cl}_{2}$ kalomelelektródot alkalmaztunk. A mérések során az elektrolit hőmérsékletét $37 \pm 1^{\circ} \mathrm{C}$-os hőmérsékleten tartottuk, és kis fordulatszámon (80 fordulat/perc) folyama-

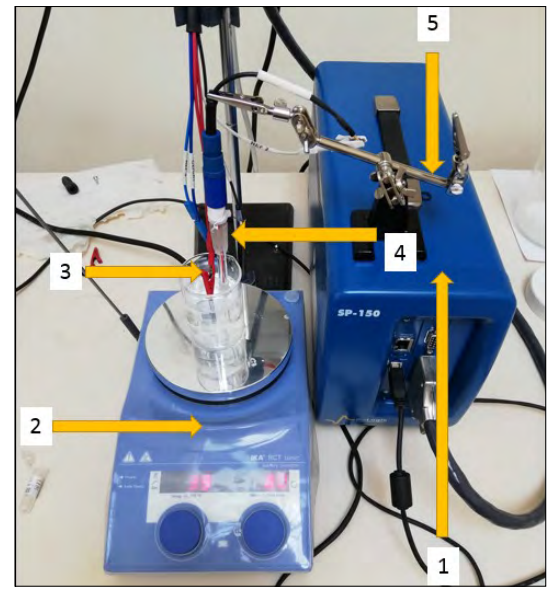

7. ábra. Az OCP-méréshez használt kételektródos cella elrendezése

tosan kevertük. A mérési elrendezés a 7. ábrán látható. A képen jelölve:

1. Potenciosztát (Biologic SP-150)

2. Füthető mágneses keverő (IKA RCT basic)

3. Munkaelektród

4. Referenciaelektród

5. Állvány

A mérések során vizsgált sztentek legfőbb jellemzőit: alapanyag, bevonat anyaga, tágítási nyomás (TNY) az 1. táblázat foglalja össze, valamint a továbbiakban a táblázat szerinti jelöléssel hivatkozom az egyes mintadarabokra.

A felsorolt sztentek 3600 másodperc mérési idő utáni szabadpotenciál-értékét, valamint a szabadpotenciál változását a 2 . táblázat tartalmazza.

$\mathrm{Az}$ ausztenites korrózióálló acél (X2CrNiMo18-15-3) alapanyagú sztentek szabadpotenciálértéke pozitív, valamint növekvő tendenciát mutat.

A kobalt-króm ötvözeteknél (Co-Cr-W-Ni ötvözet) négy esetben csökkenő, két esetben pedig növekvő tendenciát mutatott az OCP-mérés. Az 1.táblázatból látható, hogy a vizsgált kobalt-króm ötvözetből készült sztentek különböző gyártók termékei. A bevonat nélküli sztentek esetében az anyagösszetétel-mérési eredmények alapján megállapítottuk, hogy ugyan mindegyik sztent az alapanyagra vonatkozó ISO 5832-5 szabvány szerinti anyagösszetételnek megfelel, a csökkenő tendenciát mutató sztentek volfrámtartalma a szabvány által megengedett felső határérték (16\%), a növekvő tendenciát mutató anyagok esetében pedig az alsó határérték (14\%) közelében volt. Az S3, S4 sztentekről készített elektronmikroszkópos képeken látható továbbá, hogy a volfrámszemcsék a szemcsehatárok szélén 
1. táblázat. A vizsgált sztentek összefoglaló táblázata. A tágítási nyomás (TNY) esetében az MP a maximális megengedett nyomást, az NP pedig a névleges nyomást jelöli. Ezek a nyomásértékek a gyártók által meghatározott értékek, sztenttípusonként eltéröek

\begin{tabular}{|l|c|c|c|c|}
\hline Jel & Anyag & Bevonat & TNY & Gyártó \\
\hline S1 & X2CrNiMo18-15-3 & Nincs & MP & A \\
\hline S2 & X2CrNiMo18-15-3 & Nincs & NP & A \\
\hline S3 & Co-Cr-W-Ni & Nincs & MP & B \\
\hline S4 & Co-Cr-W-Ni & Nincs & NP & B \\
\hline S5 & Co-Cr-W-Ni & Amorf SiC & MP & C \\
\hline S6 & Co-Cr-W-Ni & Amorf SiC & NP & C \\
\hline S7 & Co-Cr-W-Ni & Nincs & NP & D \\
\hline S8 & Co-Cr-W-Ni & $\begin{array}{c}\text { Polimer } \\
\text { kötőanyag } \\
\text { nélküli }\end{array}$ & NP & D \\
\hline S9 & Fe-Pt-Cr & Nincs & NP & E \\
\hline S10 & Fe-Pt-Cr & PVDF-HFP & NP & E \\
\hline
\end{tabular}

2. táblázat. A 3600 másodperc mérési idő végén mért szabadpotenciál-értékek, valamint a szabadpotenciál változása a kiindulási potenciálértékhez képest

\begin{tabular}{|l|c|c|}
\hline Sztent & $\begin{array}{c}\text { Szabadpotenciál } \\
\mathbf{3 6 0 0} \text { mp után }\end{array}$ & $\begin{array}{c}\text { Szabadpotenciál } \\
\text { változása }\end{array}$ \\
\hline S1 & 0,0439 & 0,1167 \\
\hline S2 & 0,0424 & 0,1158 \\
\hline S3 & $-0,2097$ & $-0,0348$ \\
\hline S4 & $-0,1051$ & $-1,0767$ \\
\hline S5 & $-0,2953$ & $-0,7531$ \\
\hline S6 & $-0,2496$ & $-0,0242$ \\
\hline S7 & $-0,2256$ & 0,1157 \\
\hline S8 & $-0,2188$ & 0,1344 \\
\hline S9 & 0,1242 & 0,0680 \\
\hline S10 & 0,2173 & 0,0522 \\
\hline
\end{tabular}

helyezkednek el (8. ábra), míg az S7-es esetében a szemcsék eloszlása homogén (9. ábra). A 10. és 11. ábrán látható, hogy az S3 sztent felületén sokkal több a hiba, mint az S7 esetében, ami a gyártók által alkalmazott különböző felületkezelésből eredhet. Az egyenetlenebb sztentfelszín negatívan hathat a korróziós folyamatokra. A potenciálérték viszont mind a 6 vizsgált esetben negatív előjelü, így a tendenciától függetlenül is gyengébb ennek az ötvözettípusnak a korrózióval szembeni ellenállása, mint a másik két ötvözettípusé.

A tágítási nyomás növelése nem mutatott egyértelmű tendenciát egyik ötvözet esetében sem.

A polimer bevonatos Fe-Pt-Cr sztent nyitott áramkörös potenciál értéke a legnagyobb a vizs-

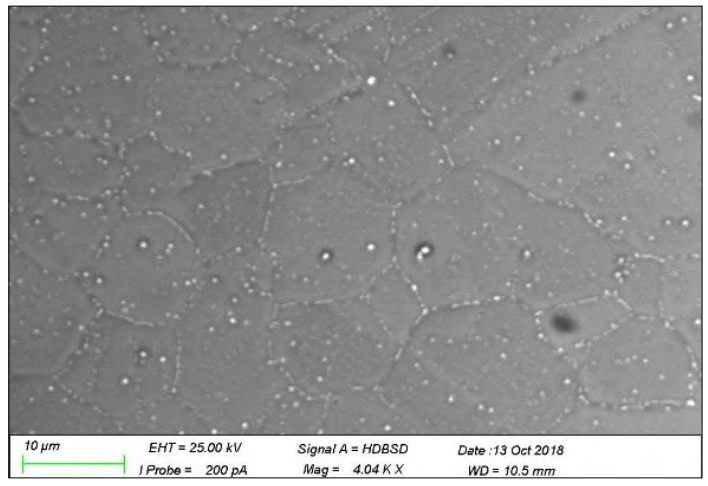

8. ábra. Az S3 sztent részletének elektronmikroszkópos képe a korróziós vizsgálatok előtt, a volfrámszemcsék a szemcsehatárok mentén

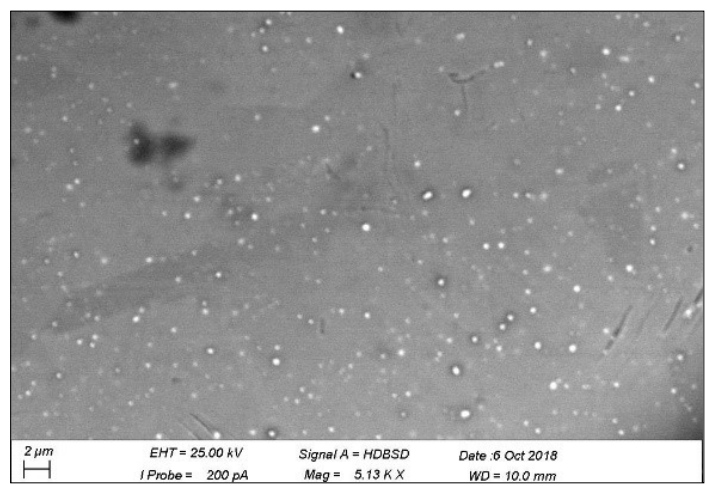

9. ábra. Az S7 sztent részletének elektronmikroszkópos képe a korróziós vizsgálatok elött, a volfrámszemcsék eloszlása homogénebb, mint az S3 sztent esetében

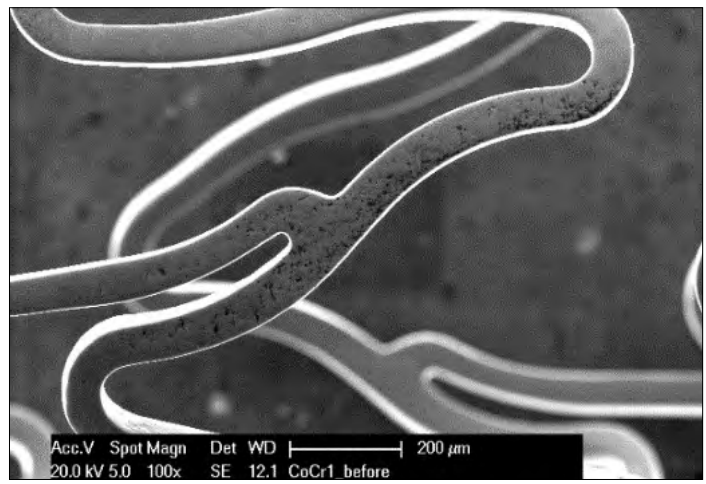

10. ábra. Az S3 sztent részletének elektronmikroszkópos képe a korróziós vizsgálatok elött

gált 10 sztent közül, ezt követik a bevonat nélküli Fe-Pt-Cr, majd a bevonat nélküli ausztenites korrózióálló acél sztentek. A polimer nélküli gyógyszeres bevonat nem befolyásolta jelentősen a szabadpotenciál értékét, ennek elsődleges oka az, hogy a bevonat egy része leoldódott a mérés során, emiatt nem tud olyan szigetelőhatást kifej- 


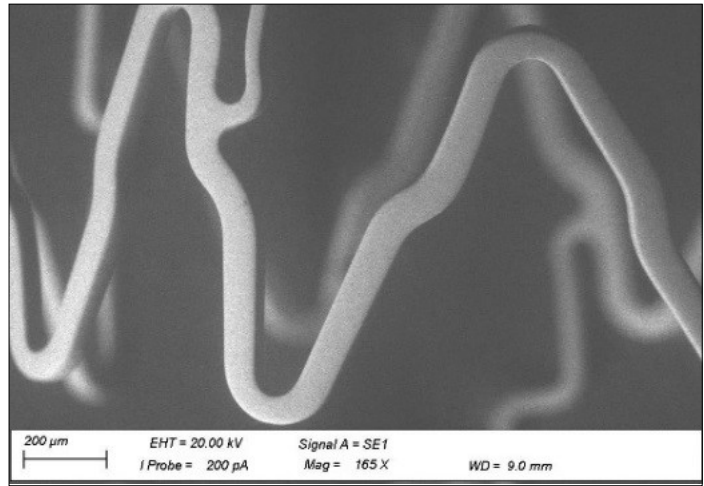

11. ábra. Az S7 sztent részletének elektronmikroszkópos képe a korróziós vizsgálatok előtt

teni, mint az Fe-Pt-Cr sztentek PVDF-HFP, vagy az S5, S6 sztentek amorf szilícium-karbid bevonata.

\section{3. Összegzés}

Jelen kutatásunk elsődleges célja egy vizsgálati módszer kidolgozása volt, amellyel a polimeres és a polimermentes hatóanyag-kibocsátó bevonatos sztentek bevonatkárosodását olyan módon tudjuk megfigyelni, hogy a vizsgált eszközök rögzítése és eltávolítása a tartóról ne járjon a vizsgált darab károsodásával. Ehhez létrehoztuk egy olyan eszköz prototípusát, amely lehetővé teszi a sztentek rögzítését és forgatását az elektronmikroszkóp kamráján belül úgy, hogy a vizsgálat közben sem a mintadarab, sem a rajta lévő bevonat nem sérül. Az így készített elektronmikroszkópos képek kiértékelésére is kidolgoztunk egy módszert, amely MATLAB szoftver segítségével számszerűsíti a bevonatkárosodás mértékét a vizsgált sztenteken.

A kutatásunk második felében nyitott áramköri potenciálos, elektrokémiai korróziós vizsgálatokat végeztünk, hogy a bevonatoknak a korróziós tulajdonságokra gyakorolt hatását vizsgáljuk. A méréseink alapján megállapítható, hogy a polimer mátrixú, hatóanyag-bevonatos sztentek korrózióval szembeni ellenállása jobb, mint a bevonat nélküli sztenteké, a polimermentes bevonat viszont nem gyakorolt jelentős hatást a korrózióval szembeni ellenállásra. Az eredményeink jó alapot szolgáltatnak a bevonatok fejlesztésére fókuszáló új kutatásainknak.

\section{Köszönetnyilvánítás}

Kutatásunk Emberi Erőforrások Minisztériuma ÚNKP-18-3-II kódszámú Új Nemzeti Kiválóság Programjának támogatásával készült. A sztentforgatóval kapcsolatos munkálatokban nyújtott segítségéért köszönet illeti Meisel Ádám gépészmérnök hallgatót.
Köszönjük a Pécsi Tudományegyetem Általános és Fizikai Kémiai Tanszék munkatársainak, hogy biztosították a mérőberendezést.

\section{Szakirodalmi hivatkozások}

[1] Mani G. et al.: Coronary stents: A materials perspective. Biomaterials, 28. (2006) 1689-1710.

https://doi.org/10.1016/j.biomaterials.2006.11.042

[2] Wienke H. et al.: Stent coating with titanium-nitride-oxide for reduction of neointimal hyperplasia. Circulation 2001, 928-933.

https://doi.org/10.1161/hc3401.093146

[3] Bognár E. et al.: Investigation of Drug Eluting Stents. Materials Science Forum, 589. (2008) 361366.

https://doi.org/10.4028/www.scientific.net/ MSF.589.361

[4] Bognár E. et al.: Investigation of Coated Coronary Stents. Materials Science Forum, 537-538. (2007) 307-314.

https://doi.org/10.4028/www.scientific.net/ MSF.537-538.307

[5] Hausleiter J. et al.: Prevention of restenosis by a novel drug-eluting stent system with a dose-adjustable, polymer-free, on-site stent coating. European Heart Journal, 26/15. (2005) 1475-1481. https://doi.org/10.1093/eurheartj/ehi405

[6] Selley T. L. et al.: Development of adhesion test for coated medical device. Biomechanica Hungarica, 2013, 303-310.

https://doi.org/10.1093/eurheartj/ehi405

[7] Ginsztler J. et al.: Development and Manufacturing of Coronary Stents in Hungary. Materials Science Forum, 537-538. (2007) 631-638.

https://doi.org/10.4028/www.scientific.net/ MSF.537-538.631

[8] Khan W. et al.: Drug eluting stents: Developments and current status. Journal of Controlled Release, 161/2. (2012) 703-712.

https://doi.org/10.1016/j.jconrel.2012.02.010

[9] Park J. K. et al.: Development of a novel drugeluting stent consisting of an abluminal and luminal coating layer dual therapy system. RSC Advances, 5. (2015) 40700-40707.

https://doi.org/10.1039/C5RA04270D

[10] Horicsányi K. et al.: Effect of Expansion Pressure ont he Drug Eluting Coating of Coronary Stents. Acta Materialia Transylvanica, 1/1. (2018) 37-40. https://doi.org/10.2478/amt-2018-0012

[11] Asztalos L., et al.: Kobalt-króm ötvözet alapanyagú sztentek korróziós tulajdonságainak vizsgálata. Müszaki tudományos közlemények, 7 . (2017) 79-82.

https://doi.org/10.33895/mtk-2017.07. 12

[12] Jiménez Y. S. et al.: Interpretation of open circuit potential of two titanium alloys for a long time immersion in physiological fluid. Bulletin of the Transilvania University of Brasov, Series I: Engineering Sciences, 2/51. (2009) 197-204. 